\title{
A Critical Discourse Analysis of COVID-19 in Ethiopia: Rethinking the Past and Defining the Present
}

\author{
Daniel Tiruneh, Getachew Baye \& Yosef Beco \\ danieltiuneh@gmail.com,getbaye@gmail.com,yosefbeco@gmail.com \\ Faculty of Languages and Humanities, Kotebe Metropolitan University, ETHIOPIA
}

\begin{abstract}
The purpose of this study is to unearth the landscape of social media and analyse the contents. Contents of social media, in Ethiopia, are varying over the course of changes in politics, health, socio-economic conditions of the country. Some of the contents are reflected in the forms of narratives, comments, briefings, anecdotes, and verses to list a few. Contents changing the way people interact with each other and share information, personal messages, and opinions about situations, objects, and past experiences- rethinking the past, themes are linked to the present and define the present Ethiopia. In order to attain the stated objective, the researchers developed critical discourse analysis as a research methodology and adapted Norman Fairclough's model of Analysis as a theoretical framework. Most social media texts are short online conversational posts or comments that do not contain enough information for a full textual analysis. Therefore, using purposive sampling six excerpts were collected from various discourses of the social media platforms, particularly Facebook, Facebook messenger, and YouTube. Based on the contexts of the discourses, the analysis was categorized thematically. The study concluded that social media users used the platform as a means to reflect both the status quo of the past and linking to the current COVID-19 and its socio-economic impacts. COVID-19 is depicted as a disease, resulting from human wrongdoings, very dangerous which is deadly even to Satan. It is also depicted as a warrior, an extremely hungry predator looking for its prey, ready to eat up human being ravenous without a need for proper chewing.
\end{abstract}

Article information

Keywords: Social media; text; representation; Coronavirus

DOI: 10.24071/joll.v20i2.2608

Available at https://e-journal.usd.ac.id/index.php/JOLL/index

This work is licensed under a Creative Commons Attribution-ShareAlike 4.0 International License.

\section{Introduction}

The 21st century has seen profound changes in the configuration of family life in sub-Saharan Africa with important implications on the health situation of the society. The prominent feature of the living conditions of the continent is typically interdependent; predominantly accompanied by a large family and communal way of life. Although these are the basis for the values of the people, it has also a repercussion on the spread of infectious and contagious diseases in the continent. This is due to the great challenge of this century to raise people everywhere to a decent standard of life and health facilities. 
Effective public health intervention is very important to curb contagious diseases. Nevertheless, African societies are still suffering from infectious diseases due to the weakness to effectively and efficiently deliver health facilities and systems (Kiringa and Barry, 2008). From homegrown experiences and practices, indigenous societies develop their own way of mitigating the spread of diseases (Yosef, 2017). Governments in Africa have a get-out for traditional medicines in their policy of health. Evidently, scores of African health policies confer prior prevention mechanism due to the high rate of population growth and lack of medical facilities.

The African population is rapidly growing over the course of the last two decades. It is the second-most-populous continent, after Asia with over 1.3 billion populations. Amongst all the continents, Africa's average population is the youngest group. Eastern Africa is the second populous sub-region with greater than 401 million populations. Ethiopia is the second populated country with over 114 million populations.

Ethiopia has also been following a prevention mechanism of health policy over the last three decades. The natural reason seems it does emanate from its longstanding

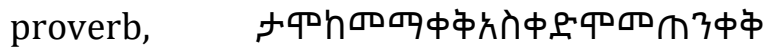
"prevention is better than cure". The idea is referred to as caring is better than suffering a pain. The Ethiopian growth transformational plans have become a leap forward for the recent economic growth. The lives of millions of prior victims like children and women have been protected, millions of new infections and death from communicable diseases such as HIV, malaria, and tuberculosis have been averted. All this was done while building a health system that can sustain the gains over the long term (HSTP, 2015). Advances in education, internet, health, and poverty reduction have contributed to the overall improvement in the health of Ethiopians.

Despite the impressive progress made, the country's hurried rise of the population is still a weakness to the health service delivery $(\mathrm{MoH}, 2015)$. Ethiopia still has high rates of morbidity and mortality from preventable causes. There is also a disparity in uptake and coverage of high impact interventions amongst different regions and woredas. The quality of health care in terms of improving patient safety, effectiveness, and patientcenteredness, in both public and private facilities, is often inconsistent and unreliable (HSTP, 2015).

The coverage of the internet in Ethiopia is enormously reaching millions of people. People's use of social media is increasing exceedingly, particularly in the last two decades. In the past two years, following the political change in the country, social media are inculcating issues of politics, society, health, education, and religion to list a few. However, the social discourses of the society towards health in general, critical aspects of health as reflected in social media in particular, are not widely studied in the field of language and communication. Hence, this study will answer the following research questions:

1. How is the Coronavirus depicted by the society and reflected in social media of Ethiopia?

2. What are the recurrent themes or issues of COVID-19 reflected in the platform of social media?

3. How are the present discourses linked to the past status quo and what lessons could be learned?

\section{Methodology}

This study sets out to critically analyze the social discourse of COVID-19 as reflected in social media. Since the study is on social discourse, it is qualitative in its design. A research on discourse, as to Trappes-Lomax (2004), " ... is mainly qualitative because it is inherently interpretive."

The social media is perhaps the hugest platform where literate people throughout the globe express their ideas, observations, life philosophy, and views freely. In view of this, there is cumbersome data on social issues. Regarding sample selection on discourse analysis from such bulky data sources, van Dijk (2001) notes that discourse analysts have to select texts that help answer specific research questions about social concerns. Therefore, the texts, conversations, dialogues, interviews, and images on COVID-19 were purposely 
selected with the purpose of getting sufficient data to help answer the research questions. The research materials for this study were collected from the social media such as Facebook, Facebook messenger, and YouTube.

The data to be collected were organized based on the recurrent themes. The data collected were written in Amharic. Yet, the analysis of the data was made in English, finally necessitating a translation. In order to let readers of the analysis have access to the data, the original and the translated data were presented side by side. Doing so, as to
Nikander (2008:299) "favors transparency and makes the author directly accountable for the translation. This way the acceptability of the translation constructed remains, at least potentially open to challenge and suggestions of alternative improved versions".

As the analysis is a critical analysis of the data circulating on social media, Fairclough's (1989), (1992) CDA framework was applied. Fairclough (1989) outlined three phases of the CDA framework: Description, Interpretation and Explanation.

Norman Fairclough's model of Analysis

Adapted from Maposa (2015) and Maalej (2007)

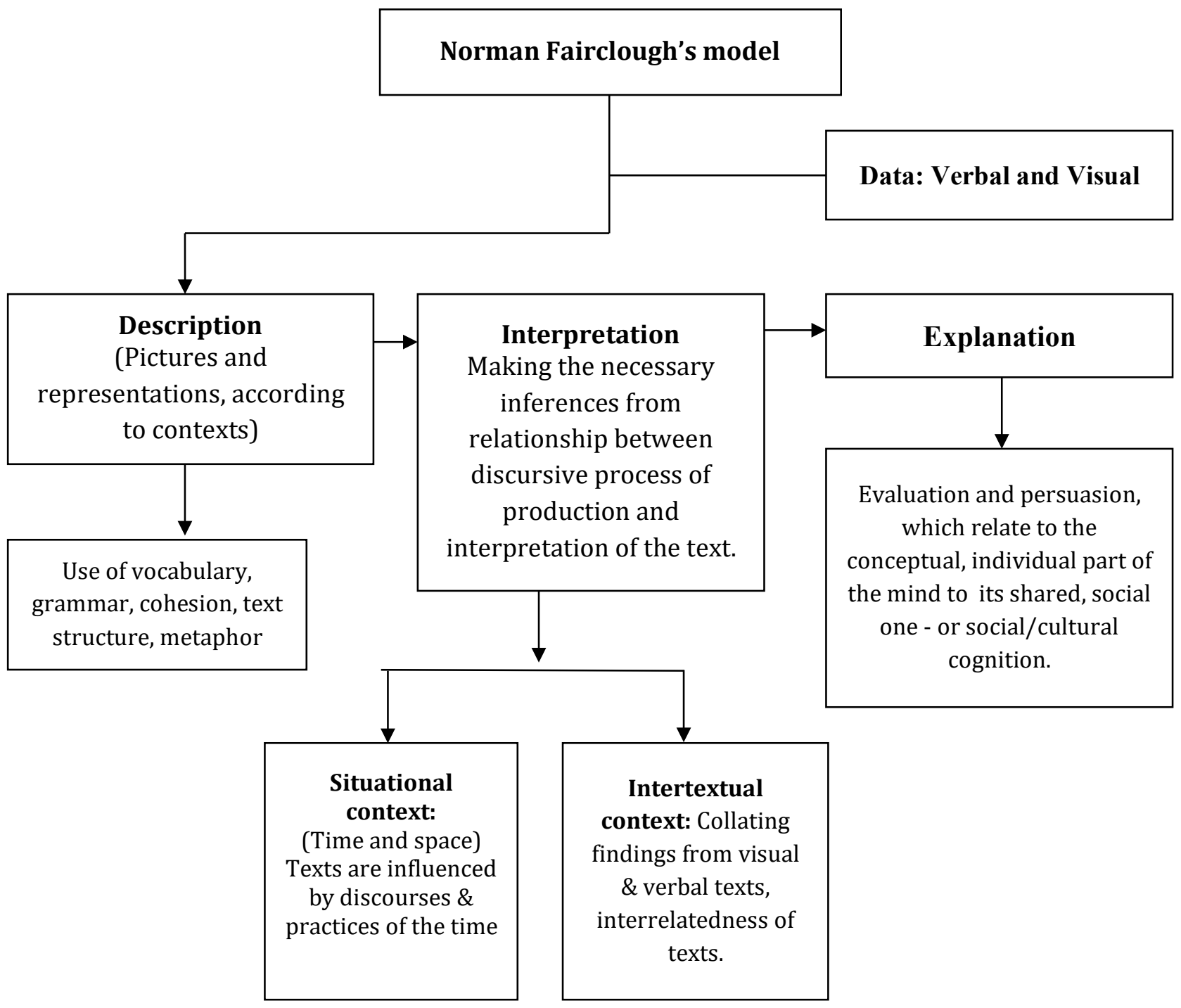


In the description, interpretation and explanation of data, visuals, where found appropriate for illustration, were presented. Visual representations, as to Hatch (2002) "should be there because they help clarify the case you are trying to make."

Description: The first dimension in Fairclough's model for Critical Discourse Analysis is a description in which discourse is viewed as text. To Fairclough (2003), the analysis of texts deals with the linguistic forms of texts and the distribution of different linguistic forms across different types of texts. Fairclough contends that text analysis alone is not sufficient for discourse analysis, as it does not shed light on the links between texts and societal and cultural processes and structures.

Interpretation: The second dimension in Fairclough's (1992) model is an interpretation which sees discourse as discursive-practice. In this dimension, Fairclough considers discourse as something which is produced, circulated, distributed, and consumed in society. These processes, Fairclough explains, are viewed largely in terms of the circulation of concrete linguistic objects. Different social contexts make texts produced and consumed differently. Some texts, depending on social context, require full attention and close inspection while others require partially focused attention while the participants are doing something.

Explanation: The third dimension in Fairclough's CDA model is an explanation where discourse is viewed as a social practice. This dimension focuses on the ideological effects and hegemonic processes in which discourse is seen to operate. Ideology, for Fairclough (1995) is 'meaning in the service of power.' To him, ideologies are constructions of meaning and representations of the world that contribute to the production, reproduction and change of relations of supremacy (Fairclough, 2003).

\section{Results and Discussion}

This section deals with the discussions and results of the data. The data, as discussed above, are discussed using Fairclough's CDA model.

\section{A Critical Discourse Analysis of COVID- 19 Alluded to Religion}

The Coronavirus pandemic has been a global health threat for the last four months now. Like any other country in the world, Ethiopia is currently taking steps to prevent the deadly virus since the first case was identified on March 13, 2020. While this study is being conducted, Ethiopia has already registered three coronavirus deaths and close to 120 cases. It is amidst this pandemic that the texts for the analysis were created by different authors and collected by the researchers.

Text 1

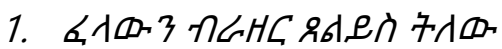

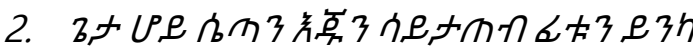

1. When you tell the little baby brother to pray, [he would say]:

2. Oh Lord, let the Satan touch his nose prior to washing his hands.

Dan Yirga, retrieved from facebook, 2020.

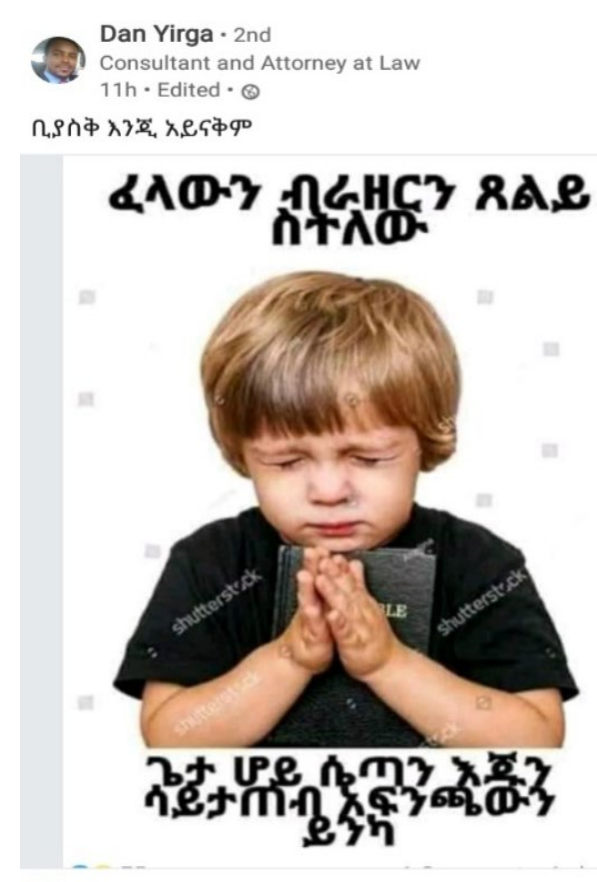

The child whom the author of the text tells to pray is a little baby, perhaps not older than four, as can be deciphered from the picture above. The child is a Christian baby as he is seen holding the Bible. He seems to be having focused prayers: closing his eyes, lifting his 
hands and perhaps knelling. However, the baby has not taken the initiation to pray by himself as the clause "When you tell the little brother,.." suggests (Line 1). The transitive choice of the texts' creator shows that he has a perceived power over the child. By the time this text was created, the Ethiopian Religions Council had declared a one-month long national prayer. The author of the texts above, therefore, seems to have drawn on this already existing social discourse.

The baby, as the text above shows, is a known baby with a definite marker $-u$ in Amharic $(6 \lambda \downarrow-3)$. The one instructing the baby to pray is neither his father nor his mother as he has used the word brother. The one giving the instruction to pray is masculine and the one to whom the instruction is given is masculine as well, which seems to have left prayer solely to males.

Prayers at the age of the child in the picture above are about blessings, prayers for a good day, for family members or just thanking God for His love and protection. From this perspective, the child should have uttered such words since these are what we presume to be in his head, what Fairclough (1989) calls Members' resources which are "the representations of the natural and social world they inhabit, values, beliefs, assumptions and so on." Contrary to this, the child prays to God to make Satan touch his nose before washing his hands. This shows that everybody in the society is so much engrossed with washing hands that even small children talk about it in their prayer- thereby establishing a new social world as texts are important forms of social practices which contribute to the establishment of social world (Fairclough, 1989).

The texts' creator seems to be alluding to the dominant biblical discourse which narrates the enmity between man and Satan as stated in Genesis 3:15, "And I will put enmity between you and the woman, and between your seed and her seed; it shall bruise your head, and you shall bruise his heel." Satan, who is believed to have taken the serpent's image to deceive Eve, is believed to seduce human being to evil acts. Based on this, the child reiterates, through intertextuality, the thousand years old biblical discourse in Genesis 3:15.

By mentioning washing hands, the writer echoes the current situation created by COVID19. The baby prays to God and wishes that Satan touch his nose with his unwashed hand so that it will catch the deadly virus, which is an allusion of the enmity in the Scripture.COVID-19, in this case, is depicted as the most dangerous disease which is even capable of killing Satan who has a spiritual being, which is a hyperbole. Besides, the writer focalizes the voiceless child in order to voice his message demonizing the disease. Nelles (1990) states that a writer uses certain form of techniques to present information by depersonalizing him/herself and focalizing other characters. Likewise, the writer is lacking definable personality in the above short narrative. Behind the scene, he paints the horrible picture of the disease through the voice of an innocent child.

\section{Discourses Enacting Social Media}

The data for this analysis come from an interview between a journalist and an Ethiopian Orthodox Tewahido Church Archbishop. An Archbishop, always male, in the Church's tradition is one who administers one boundary of a diocese. An Archbishop is also a member of the Holy Synod which has the ultimate authority in matters of faith and church administrations.

For the sake of this analysis, we refer to the Archbishop as Father Samuel (not his real name). The Archbishop being interviewed appears in his liturgical vestments and with a cross in his hands enacting a socially meaningful identity as a spiritual head of the Church. As Gee (2018) argues "Discourses are ways to enact socially meaningful identities, using language and "other stuff". 
Table 1. Extract from Archbishop, Father Samuel's interview

\begin{tabular}{|c|c|}
\hline Amharic & English \\
\hline 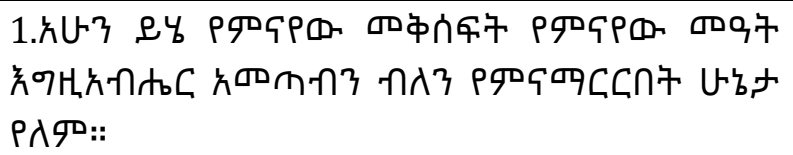 & $\begin{array}{l}\text { This calamity we are witnessing now } \\
\text { There is no way we can complain that God has } \\
\text { brought it on us. }\end{array}$ \\
\hline 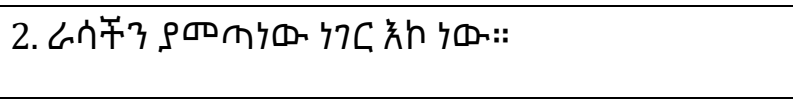 & $\begin{array}{l}\text { This is something that we have brought } \\
\text { ourselves. }\end{array}$ \\
\hline 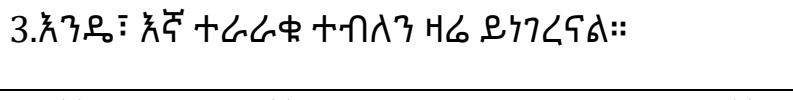 & $\begin{array}{l}\text { (What do you mean?) We are told today to keep } \\
\text { our physical distance. }\end{array}$ \\
\hline 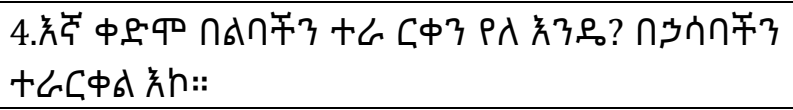 & Are we not already far apart in our hearts? \\
\hline 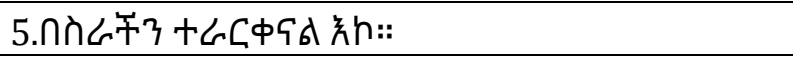 & We're far apart in our deeds. \\
\hline 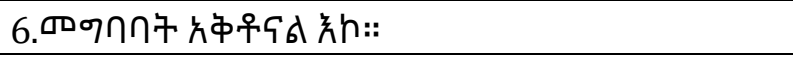 & We are unable to understand each other. \\
\hline 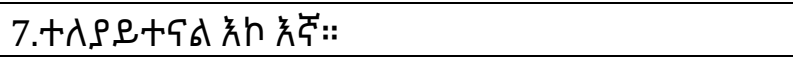 & We're separated. \\
\hline 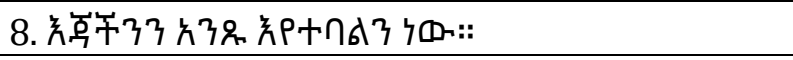 & We are being told to keep our hands clean. \\
\hline 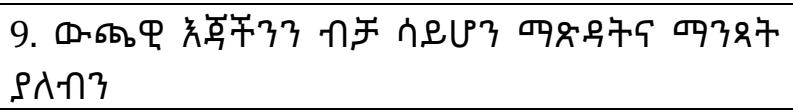 & We should not clean just our outer hands. \\
\hline 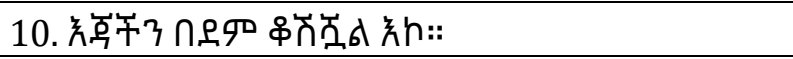 & Our hands are stained with blood. \\
\hline 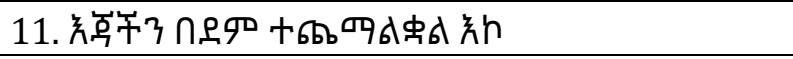 & Our hands are filled with blood. \\
\hline 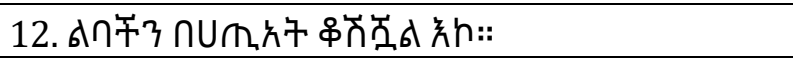 & Our hearts are defiled with sin. \\
\hline 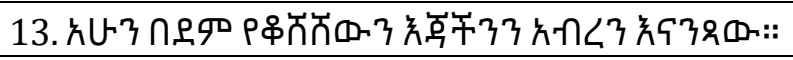 & Let us now clean our hands stained with blood \\
\hline 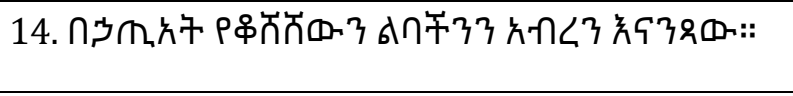 & $\begin{array}{l}\text { Let us also clean our hearts, which are defiled } \\
\text { with sin. }\end{array}$ \\
\hline 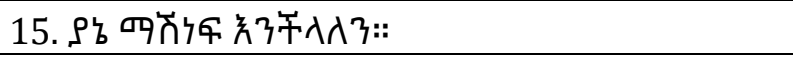 & Then we can win. \\
\hline 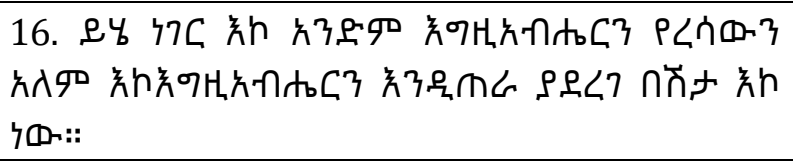 & $\begin{array}{l}\text { This thing is a disease that, for one thing, has } \\
\text { caused the World that has forgotten God to cry } \\
\text { out to Him. }\end{array}$ \\
\hline
\end{tabular}

Father Samuel prefers to use a special wording (Line 1) and describes COVID -19 as a calamity, there by labeling it as a devastating disease marked by great loss and lasting suffering. The Archbishop is arguing that the pandemic or the 'calamity', in his own word, is the result of a social wrong (an expression Fairclough, 2012 uses). He uses the intensifier or the emphatic reflexive $\mathrm{L}$ ก年3'ourselves' (Line 2) to say that we, not anyone else, caused the pandemic. Father Samuel uses objective modality to reinforce the power of his statements that we caused the pandemic presenting them as facts independent of the speaker rather than as merely subjective opinions. According to Jørgensen and Phillips (2002), "objective modality is used "to construct the statements as facts rather than views based on the speaker's own personal interests." To confirm that this is a fact, not his opinion, he uses the Amharic interjection 紟 (Lines 4, 5, 6 and 7).

What social wrongs the Archbishop is referring to is not easy to pin down straightforwardly from the linguistically presented texts. From our 'shared knowledge' as Gee (2010) calls it, we presume that hatred speeches, killings, corruption, selfishness, greed and such wicked behavior that have been observed in Ethiopia recently are possible wrongs of the day which have brought about dire consequences the Archbishop is referring to.

Without mentioning the doer/the teller, he states that we are told to keep distancing (Line 3). He uses non-agentive passive constructions and opts for indirect discourse presentation in a passive form $(\mathrm{e}$ לา८ 9 , 'we 
are told'). Following the first pandemic case in Ethiopia, there has been a demand from the Government that people stay two meters far apart from individuals coughing. This is what Father Samuel is making reference to. By using the first person inclusive pronoun 'we' he seems to be referencing everyone in Ethiopia, even possibly in the world.

He assertively states that the people are far apart in three ways: in hearts, in thoughts and in deeds (Line 4-5). According to him, we are distanced in heart from each other to the extent of failing to understand each other when he says "Are we not already far apart in our hearts?" (line 4). He also adds in Line 5, and tells us that we are separated in action. In view to this point he says, "we're far apart in our deeds."

Unlike English and other languages, Amharic, as a pro-drop language, does not require an overt subject in declarative sentences. Therefore, the subject pronoun is often deleted. However, the speaker in line 4 uses the subject pronoun ( $\left(\begin{array}{c}5 \\ \overline{5}\end{array}\right.$ we) to emphasize the fault we are at. In $+\lambda \rho \mathcal{e}+5 \lambda$ ('we are separated'), the morpheme-' $h d$ refers to first person plural and the pronoun we is not necessary as the sentence without the subject pronoun can stand meaningful and grammatical correct. The speaker uses both the morpheme - $h d$ and the subject pronoun ${ }^{2}$ ' ('we') to emphasize that we are all at fault. By assigning agency to the collective rather than to someone or a few individuals by using the first person plural pronoun, he constructs wrong doers' identity and he attributes it to everyone.

Father Samuel portrays himself and others as someone who will have to abide by what he and others are told (Line 8). He uses agentless passive voice which leaves undetermined who might do the telling. In other words, it is not clear who the demand is attributed to. According to Gee (2010:153), all utterances make assumptions about people's previous experiences and knowledge. From our previous experience, we know that we are being told to clean hands by the Government following the pandemic in Ethiopia. This is what the assumption (that we know it) the speaker has in his mind. Such assumptions and previous knowledge that people have in their heads and draw upon when they produce or interpret texts - including their knowledge of language, representations of the natural and social world they inhabit, values, beliefs, assumptions and so on" are called 'Members' Resources' (Fairclough, 1989: 24).

It seems that Aba Samuel has given more attention to what is being told than who is doing the telling. Yet, he is appreciative of the information/demand as he welcomes it as he says 'very good' in line 8 . He refers to the popular social discourse of the day- personal hygiene, as a buzz-word in the wake of the pandemic to which the audiences of all kindslisteners, viewers, and readers know about. He gives prominence to not the physical cleanliness, but to the spiritual one. True victory over the pandemic will be achieved when we clean our hands which are stained with blood, not just with the virus or dirt (Line 15).

In line 10 and 11 , the speaker uses hand as a theme, and constructs rhems (Brown and Yule, 1983:126) such as stained with blood and filled with blood. We also notice that there is a theme reiteration (Line 10 and 11), perhaps to show that we showed wicked behavior via our hands.

Aba Samuel uses the word blood to metaphorically denote the act of murdering and shedding blood. As a Christian leader, Aba Samuel is alluding to the Biblical discourse, without explicitly cueing it, about murder and shedding blood, which he might have assumed the audience knows about. His allusion might be assimilating to the Biblical discourse found in Matthew 23:35 "That upon you may come all the righteous blood shed upon the earth, from the blood of righteous Abel unto the blood of Zacharias son of Barachias, whom ye slew between the temple and the altar." Gee (2011: 58) calls such an allusion an 'intertextuality'.

The pandemic is metaphorically represented as a warrior and we are in a battle. We will be victories over the disease (Line 14) when we clean ourselves through washing hands and hearts defiled with wicked behavior 
(Line 13-14). By referring to heart (line 112), the Bishop is not referring to the physical heart which pumps blood to the body. Rather, he is demanding an internal or inwardly cleanliness, putting it as a criterion for winning the battle. There are a number of biblical discourses which refer to heart to metaphorically portray inwardly purity. The following are examples, but just a few:

Blessed are the pure in heart, for they will see God (Matthew 5:8).

He who has clean hands and a pure heart, who does not lift up his soul to falsehood, who does not swear deceitfully (Psam 24:4).

Surely God is good to Israel, to those who are pure in heart (Psalm 73:1).

Then they will not be like their fathers, a stubborn and rebellious generation, whose heart was not loyal, whose spirit was not faithful to God (Psalm 78:8).

The Archbishop does not seem to feel comfortable in addressing the disease in its name: Coronavirus or COVID-19. He uses euphemism and calls it as 'thing' (Line 16). In line 1, he labeled it as a calamity, and now he addresses it as a thing that has come for a good reason. However, he does not dare say with full confidence that the disease occurred solely for a good reason and hedges by saying, $\lambda 3$ p. 'for one thing' (Line 16). He justifies his statement one reason for the disease is to make the world that has forgotten God cry out to Him. Without mentioning the second or the other reason(s), he asserts that the disease occurred for good reason (Line 16).

\section{Analysis of Discourse Practices of Politics during COVID-19}

Political discourse is an intricate form of social practice that play an essential role in shaping people's thoughts and attitudes (Chilton, 2004 cited in Hussein, 2016). The strong relationship between language and political practices is already and sporadically reflected in social media in Ethiopia. After the major political reform over the past two years in Ethiopia, the current political discourse is a surge in the COVID-19 pandemic subject. The following example illustrates.

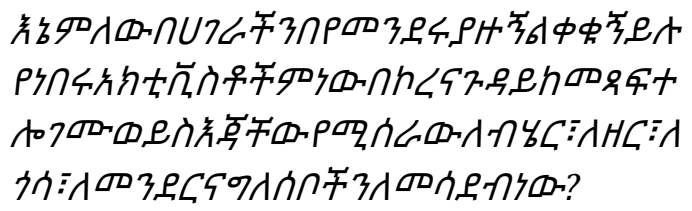

By the way, why are those conceitedly behaving activities in our country, in every village now hand-tied to write about coronavirus? Or does it mean their hands work only when it comes to ethnicity, tribalism, village level politics and downgrading individuals?

By: GutagoFonte, Posted on facebook, 21 April 2020

With incessant socio-economic and political tensions, COVID-19 has added fuel into the fire. In the present Ethiopia, the pandemic has almost switched the existing discourses to the indeterminate socio-political scenario. The activists who challenge the system directly and explain the 'plight' of the society in terms of several aspects, they remain deprived of their good share in teaching their own people and protecting them from coronavirus. Some Ethno-nationalist activists remained silent on the issue of the pandemic and this was a bizarre phenomenon, according to the writer. Many activists who use opportunistic reasons to worsen the political crisis, already kept silent since the detection of COVID-19 cases in Ethiopia. However, the discourse of the writer is subject to proof whether the activists did comment on the pandemic or not.

As for the discursive practices, the writer presents the contradictory acts of the activists in explicit language when he says, "why are those conceitedly behaving activities in our country, in every village now hand-tied to write about coronavirus? Or does it mean their hands work only when it comes to ethnicity, tribalism, village-level politics and downgrading individuals? "In view of this point, Sipra and Reshid (2013) state that critical discourse analysis focuses on how the language reflects discursive practices in the binary relations. From the point of view of the writer, the 
activists were writing about ethnic-based conflicts; likewise, they were expected to write about the COVID-19 pandemic. The text implicates that the activists should make their followers active about the disease.

The writer used words of the same category as "...ethnicity, tribalism, village" in order to depict the recurrent agenda of the activists in the past years. He says they were behaving conceitedly and raising such an agenda, whilst they hushed how to help the society during the pandemic. The writer makes a sound criticism where he believed they failed in exemplary heroism because they sidelined themselves from helping people in times of hardships.

In light of the above point, YohannisYimam has also commented against the activists who before COVID-19 engaged in many-sided conflicts. It is stated as follows:

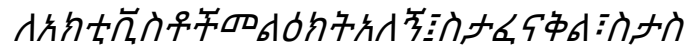 7.

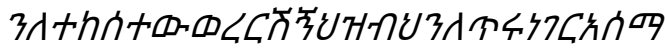

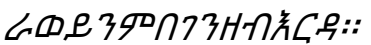

I have a message to the activists; those of you who were evicting citizens, getting them killed, burning places of worship; let you now instigate your followers for a good cause and to contribute your share in terms of money.

YohannesYimam, posted on facebook, 12 April 2020

The use of phrases like "evicting people", getting them killed", "burning places of worship", indicate how the activists trigger conflicts just for their own state of sociopolitical affairs. Had it been for the people, they could have contributed by activating the people about the disease or giving them financial aids. The comparison of the social condition of both the elite and the poor explains how the use of social media was a destructive platform to suck the blood of the poor while giving nothing in return. It also indicates the activists lent their hands for destruction rather than for kindness before COVID-19 at most.
The text relates the lexical choices used in the excerpt with broader socio-political contexts of the current Ethiopia- that the nation needs supports to the society. Sipra and Reshi (2013) state the use of parallel language that refers to the particular identification of patterns in the speech. Likewise, "evicting citizens, getting them killed, burning places of worship" draws the attention to an explicit comparison among things that are essentially similar and show something in common. The expression divulges the social condition of the masses who suffered in the past because of the flared up conflicts among the low socioeconomic society. On the other hand, the writer ironically urges those activists to stand with the people in need during the COVID-19 season.

Both writers used the discursive strategy of criticism by repeating the negative deeds like downgrading individuals, conceitedly behaving, refraining from writing on issues related to the pandemic, evicting citizens, getting people killed and burning places of worship. The wordings portray that the activists exacerbate social conditions in Ethiopia. Any discourse whether written or spoken from the perspective of discursive practices in a society reflects hegemony, domination, inequality of basic rights and racial discrimination (Van Dijk,1998a, cited in Reshid and Sipra, 2013). The writers examine the effort of these practices with reference to socio-economic and political perspectives. Due to the activists' words, individuals downgraded citizens, evicted them, burnt worship places, to list a few. Contrary to the activists' silly agenda, the writers interrogate the activists to respond by writing on issues related to the pandemic, instigating their followers for a good cause and contributing their share in terms of money. In general, instead of salient ideological components of socio-political discourses, the activists served deprivations of citizens' social and political conditions by implicating more instant conflicts and less social welfares. 


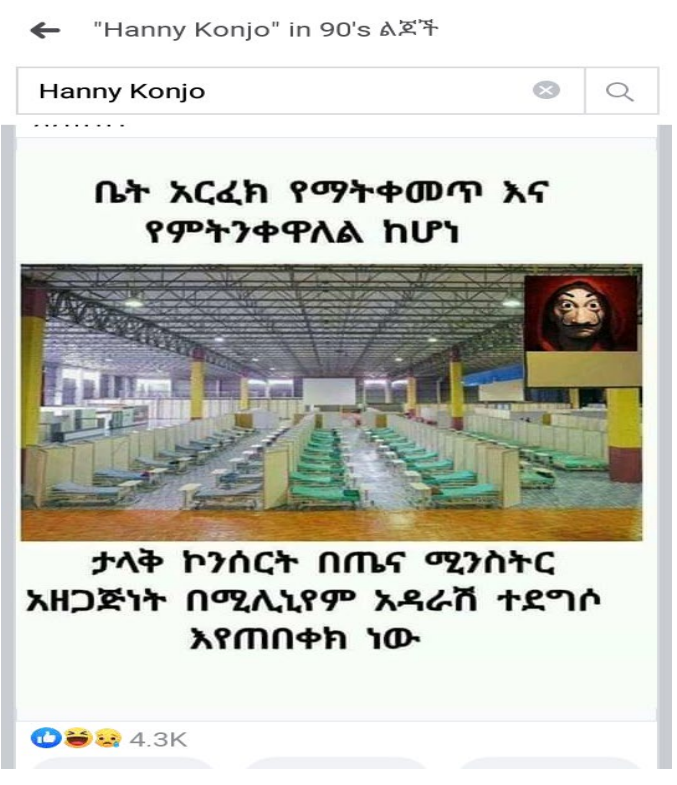

\section{Harnessing health Promotions through Representations}

If you do not stay at home, but rather loiter, a huge concert organized by the Ministry of Health is awaiting you at the Millennium Hall.

The whole world, including Ethiopia, has been grappling with the pandemic triggered by COVID -19. Ethiopia, as a country, is exerting an effort in the prevention of the spread of the virus through testing, identifying, isolating and providing treatment. To this effect, the Federal government is engaged in preparing different places that could serve as treatment centers for the provision of medication services to the citizens living with the virus, and one of these places is the Millennium Hall. The above statement with the picture was written at the onset of COVID-19.

The picture above is that of the Millennium hall, built twelve years ago with the aim of celebrating the Ethiopian Millennium which is behind 7 or 8 years from the rest of the world. This hall is a multipurpose one, dedicated to hosting different occasions ranging from serving as a place of gathering for huge musical concerts to that of public ceremonies. At this moment, the government has been urging people, where possible to stay at home using the mainstream and other social media.
Nonetheless, following the detection of COVID-19 in the country and as part of the government's effort to fight the pandemic, the Ethiopian Ministry of Health has now changed the Millennium Hall to a treatment center that in case the number of people who could be victims of the virus would escalate and go beyond the capacity of other hospitals. This millennium hall, which in previous time was serving as a place for huge musical concerts, among others, has now been organized to host around 1000 beds for Covid-19 patients along with over 140 beds for ICU patients.

In a semiotic analysis, discourses are uncovered from symbolic representations (Yosef, 2017). Social realities and meanings are depicted in representations. In the picture, the picture at the upright section of the hall, there is a monster like a creature which the writer might have used it to show to the audience how terrible this virus is and such a representation of an idea is referred to as semiosis. With this representation, the writer is eliciting some actions such as deciding to sit at home or inhibiting some actions such as going out and loitering. The writer seems to be highly satiric in that this multipurpose hall that became the epicenter for most of the jubilant practices if not always, has now turned itself into a "battlefield" for the seemingly inevitable fight the country is about to engage with this nasty virus. The writer seems to be keen to tell us the fact that this virus is setting a mounting danger on our people in that let alone our hospitals which are under normal circumstance meant to be centers of medication, even this Millennium Hall which was mainly known for being a jubilation center has turned itself into a hospital. The writer has mainly used this message to warn us how horrible this virus is if it outbreaks due to reckless behaviours in Ethiopia.

In the Amharic version, the writer referring to 'you' implies that in many instances of our context, a masculine that equally refers to both sexes. Such a remark is usually used in many legal documents including the country's constitution as well (The FDRE constitution 1995). By saying "If you do not stay at home, but rather loiter, ......" the writer, with her ill-feeling, is trying to address those who are simply careless and 
roam around, they are expected to remain aloof and stay at home where they can have a safe sanctuary from being exposed to COVID19. The fact that the author has used an 'if' clause which could roughly be equivalent to the probable condition of the English version, appears to be expressing the likelihood of many to go out of home without having anything to do irrespective of what is aired day and night by the media in advising people that the safest way of securing ultimate protection from the coronavirus is staying at home.

Metaphor is not a matter of language but of thought; it is understanding and experiencing one kind of thing in terms of another (Lakoff and Johnson, 1980 as cited in Guo, 2013). In the extract the writer uses a metaphoric expression that states " ..... huge concert" corresponds to a hall that is used to host a musical concert, "Millennium Hall" to "treatment center", and a hall with thousands of seats replaced by a huge number of beds. From the excerpt in "a huge concert organized by the Ministry of Health is awaiting you at the Millennium Hall", implies two things. The first one is that the writer appears to have been interested to give focus on what is organized, i.e. the latent misery caused by a coronavirus. The second one is that the writer is interested to mention the organizer, The Ministry of Health. The idea that having neglected the remark by the Ministry of Health would have an atrocious effect on citizens' lives. The writer though she is interested in the recipient of the action instead of the doer, it appears to be a deliberate act on the part of the author to mention the organizer, The Ministry of Health, as the doer of the action through the "by phrase' which otherwise could have been left out.

Owing to this, the text's portrayer seems to be warning Ethiopians who are not observant of strict advice of the Ethiopian Ministry of Health which are almost always given by it on how to stay safe from the corona pandemic. As an instance, the Ministry in its Facebook page posted on April 7, 2020, stated the following"

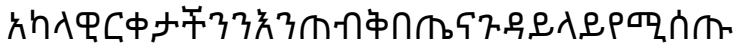

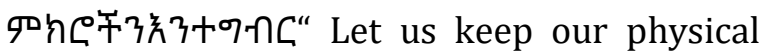
distance and, implement advice on health matters. "The Ministry urges the citizens to respect orders and protect themselves from the infectious disease. In her satirical statement the writer implies that if the society continues with such a negligence (especially if not maintaining social distancing) towards the pandemic, there could be the possibility for everyone to come to this Millennium hall, not for participating in the musical concerts but rather to be in between life and death once they contracted the coronavirus.

From the whole extract, one can also infer the power relation between actors and actresses in communication. For example, the writer of the text by saying if you prefer loitering instead of sitting at home ....that a huge concern is awaiting you at the millennium hall shows that violation of advice by the concerned would be resolved through coercion instead of consensus. This reminds us of a popular Amharic saying"

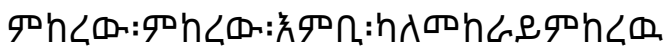
which means "one who ignores advice shall suffer the consequence".

\section{Social Cooperation during the Pandemic}

The data for this analysis come from a Facebook user called Temesgen Huneganw. In his Facebook page posted on May 01, 2020, he argues that social cooperation is vital to be victories over the pandemic.

Table 2. Extract from Temesgen Huneganw

\begin{tabular}{|c|c|c|}
\hline & $::$ & \\
\hline 2 & 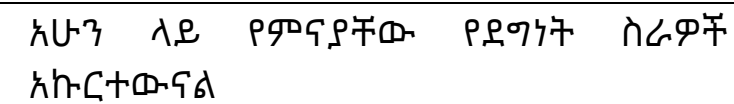 & 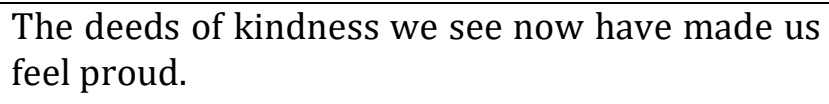 \\
\hline & 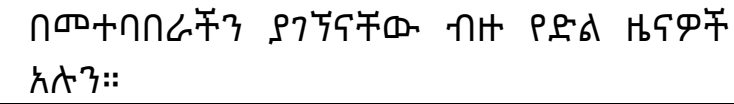 & $\begin{array}{l}\text { We have many victory stories from our } \\
\text { collaboration. }\end{array}$ \\
\hline
\end{tabular}




\begin{tabular}{|c|c|}
\hline 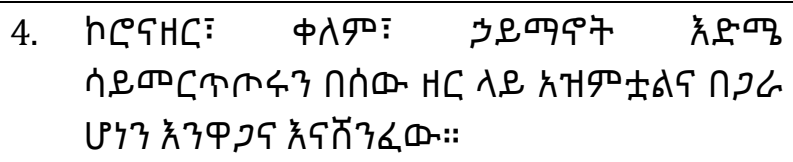 & $\begin{array}{l}\text { Corona has waged war on everyone, irrespective } \\
\text { of race, color, religion and age. Let us fight and } \\
\text { conquer it together. }\end{array}$ \\
\hline 5. $\quad$ ก & e. \\
\hline 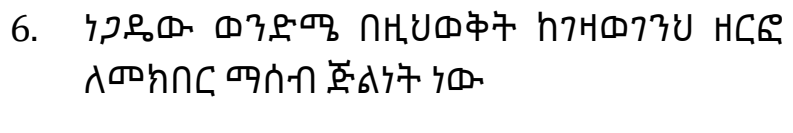 & $\begin{array}{l}\text { think to } \\
\text { at his tim }\end{array}$ \\
\hline 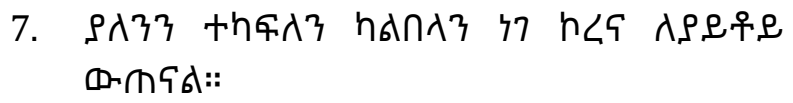 & $\begin{array}{l}\text { If we don't share what } \\
\text { devour (devours) each of } t\end{array}$ \\
\hline 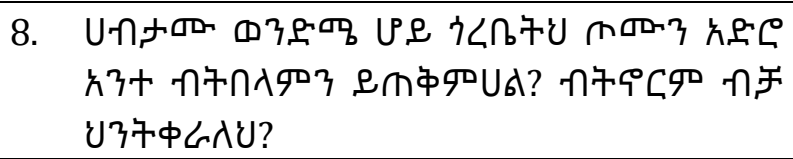 & $\begin{array}{l}\text { My rich brother, what good is it } \\
\text { neighbor goes hungry and you eat } \\
\text { will live alone }\end{array}$ \\
\hline 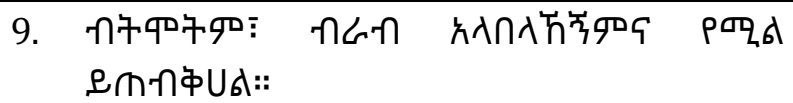 & $\begin{array}{l}\text { I was hungry you gave } \\
\text { ou. }\end{array}$ \\
\hline 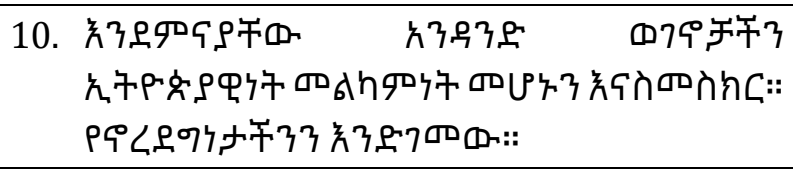 & $\begin{array}{l}\text { Like some of our people we see now, let's testify } \\
\text { that being an Ethiopian is a virtue. Let's reiterate } \\
\text { our long lived kindness. }\end{array}$ \\
\hline 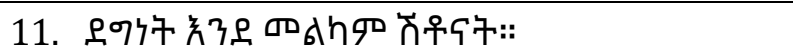 & \\
\hline
\end{tabular}

The text author, Temesgen in his Facebook account, starts his speech by an endearment term by using the Amharic morpheme-e (my) in Ф79年. By using the endearment term (my) from the outset, he seems to be creating a relaxed and friendly atmosphere with his readers.

Without using 'explicit modalizing elements' (Fairclough, 1995), Temesgen makes an assertion and puts it as a categorical fact that there are many victory stories resulting from cooperation. By using the simple present tense, he shows his commitment to truth and his knowledge to the truth, the latter being 'epistemic modality' (Fairclough, 2003).

Corona is described as a warrior (Line 4) and as an extremely hungry predator looking for its prey (line 7). The verb वाप (to devour

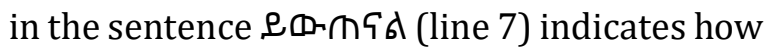
the virus is ready to eat up human being ravenous without a need to proper chewing.

The text writer uses simple present tense and expresses a strong commitment to his proposition that greed is bad (Line 5). Though Temesgen uses the possessive marker morpheme (-e) in $\square 3 \mathrm{P}^{\circ} \mathrm{Q}$ (my brother) and singular noun $\triangle 3$ P $\mathcal{F}^{\circ}$ (brother), he is referring to every literate male Facebook user. The words naïve and loot (line 6) are used to show the degree of the writer's hatred towards greed and the need for kindness and cooperation during this pandemic. Traders have raised prices (which was condemned by the government as an illegal activity) just in the first-week Coronavirus was confirmed in Ethiopia. The act of increasing prices is what Temesgen labels as looting. Without citing instances, Temesgen tells readers that kindness is a long-lived virtue in Ethiopia. By using the first person plural pronoun, he encourages everyone for a kindness act (Line 10).

Temesgen puts what he labeled as greedy rich people with dire consequences should they fail to cooperate with the mass, an avoidance approach: being alone on earth or facing a tough question during the time of the Final Judgment (line, 8 and 9). He alludes to the biblical text without directly or indirectly citing the source. In Christianity, it is believed that Jesus will come to earth for a final judgment, the day the world ends, placing people on his right and on his left (Matthew $25: 32$ ). One of the things Jesus will say to those 
on his left is "When I was hungry you gave me nothing to eat" awaits you.". This is what Temesgen has alluded to which is a defiant behavior of refusing to help out other fellow human beings in need such as during the pandemic world crisis.

The government of Ethiopia has taken stringent measures against those who increased prices, including snatching business licenses, closing trade shops and giving warnings. This is what Fairclough (1989) calls power through coercion. Temesgen, on the other hand, uses the dominant biblical ideology to win the consent of the people for cooperation, power through consent (Fairclogh, 1998). According to Fairclough (1989) "ideology is the prime means of manufacturing consent." In Ethiopia, religion has held a significant role in shaping the society and Temesgen is using the religious ideology to reproduce societal power.

The writer states that there are some people who are getting involved in kindness deeds. He uses the inclusive first-person plural and their kinds deeds have been witnessed by all (line 10, we see now). He is, however, worried that the number of such people is not enough. In Ethiopia, some people have positively responded to the Government's call for cooperation and they gave buildings and even their own private cars. It is to such people that Temesgen is referring to.

Kindness is metaphorically described as a perfume (line 11). By comparing an act of kindness and perfume, the writer describes his affinity with kind-heartedness. This is what Fairclough calls (2003) " the process of texturing self-identity".

\section{Conclusion}

Social media proves to be valuable instruments for effective critical analysis of speakers' or writers' discourses on different issues. It can verily be said that the existing situation of COVID-19 situated almost all writers and speakers from different fields and institutions to the center of common discussions on the agenda. The thematic shift is shown up after the past political tensions are replaced by social welfare. Class difference is subdued due to COVID19- the plight of ordinary people is brought to forth, the rich gave their possessions to the rest of the poor masses of today's Ethiopia. During the unprecedented horrific time of the coronavirus, writers criticized those who were causing social injustices, economic inequalities and political deprivation in the past Ethiopia. As a result, writers in social media propose to challenge the status quo by carrying out social media revolution to transform the society into the strongest inspirational content which is an important factor to establish egalitarianism in today's Ethiopia.

\section{References}

Chouliaraki, L. and Fairclough. N. (1999). Discourse in Late Modernity: Rethinking Critical Discourse Analysis. Edinburgh: Edinburgh University Press.

Fairclough, N. (1989). Language and Power. London: Longman.

Fairclough, N. (1992). Discourse and Social Change. Cambridge: Polity.

Fairclough, N. (1993). Language and Power. New York: Longman.

Fairclough, N. (1995). Critical Discourse Analysis: The Critical Study of Language. New York: Longman.

Fairclough, N. (2003). Analysing Discourse: Textual Analysis for Social Research. London: Routledge.

Flowerdew, J. (1990). Problems of Speech Act Theory from an Applied Perspective. Language Learning, 40, 79-105.

Gee, P. (2018). Introducing Discourse Analysis: from grammar to society. London: Routledge.

Guo, S. (2013) Metaphor Studies from the Perspective of Critical Discourse Analysis: 
A Case Study of Business Acquisition. Theory and Practice in Language Studies, 3(3), 475-481.

Hatch, J.A. (2002). Doing Qualitative Research in Education Settings. Albany: State University of New York.

Hussein, I. (2016) Critical Discourse Analysis of the Political Speech of the Egyptian President, Abdel Fattah El-Sisi, at the New Suez Canal Inauguration Ceremony. International Journal of Language and Literature, Published by American Research Institute for Policy Development 04(01), 85-106 DOI: 10.15640 /ijll.v4n1a10

HSTP (2015). Health Sector Transformation Plan: The Federal Democratic Republic of Ethiopia. Ministry of Health Ethiopia.

Kiringa, J. and Barry, S. (2008) Health Challenges in Africa and the Way Forward. International Journal of Medicine, 1(1), 127.

Maalej, Z. (2007). Doing Critical Discourse Analysis with the Contemporary Theory of Metaphor: Towards a Discourse Model of Metaphor. ResearchGate. http://www.researchgate.net/publicatio $\mathrm{n} / 24355966$

Maposa, M. (2015). Reflections on applying critical discourse analysis methodologies in analysing South African history textbooks. School of Education University of KwaZulu. http://dx.doi.org/10.17159/ 2223-0386/2015/nl4a3

Mayr, A. (2004). Prison Discourse: Language as a Means of Control and Resistance. New York: Macmillan.

MoH (2015). Review of Policy Documents on Climate Change, WASH and Public Health in Ethiopia. Addis Ababa, Ethiopia.

Nelles, W. (1990). Getting Focalization into Focus, Narratology Revisited. Poetics Today. 11(02), 365-382.
Nikander, P. (2008). Working with Transcripts and Translated Data. Qualitative Research inPsychology, 5(3), 225-231.

Sipra, M. and Reshid, A. (2013). Critical Discourse Analysis of Martin Luther King's Speech in Socio-Political Perspective. Advances in Language and Literary Studies, 04(1), 27-33.

Trappes-Lomax, H. (2004). Discourse Analysis: Who Does Discourse Analysis, and Why? In: Davies, A and C., Elder (Eds.), The Handbook of Applied Linguistics (pp. 133164). Oxford: Blackwell.

Van Dijk, T. A. (2001). Multidisciplinary CDA: a plea for diversity. In Wodak, $\mathrm{R}$ and M.,Meyer (Eds.), Methods of Critical Discourse Analysis: Introducing Qualitative Methods. London: Sage.

Yosef Beco. (2012). Semiotic Discourse Analysis of Indigenous Knowledge Related to Rivers in Bale Oromo Folk Narratives. Journal for Research Scholars and Professionals of English Language Teaching. 1(2), 1-18.

Yosef Beco (2017). Indigenous Climate Knowledge as Reflected in the Forestdependent Oromo Society, around the Bale Mountains. Australia Folklore, 32, 5270. 